\title{
MIGRATION OF RAT AND FOREIGN SPERMATOZOA THROUGH THE UTERO-TUBAL JUNCTION OF THE OESTROUS RAT*
}

\author{
G. R. HOWE $\uparrow$ AND D. L. BLACK \\ Department of Dairy and Animal Science, University of Massachusetts, Amherst, \\ Massachusetts, U.S.A.
}

(Received 28th August 1962)

\begin{abstract}
Summary. Immotile rat, rabbit, bull and human spermatozoa, alone and in combinations, were introduced into the uteri of oestrous rats. At intervals after introduction of sperm cells, the animals were killed and the contents of each oviduct were examined for the presence of spermatozoa. The utero-tubal junction did not appear to select against the passage of foreign spermatozoa nor was motility essential for transport through the junction.
\end{abstract}

\section{INTRODUCTION}

The role played by the utero-tubal junction in spermatozoan transport is not clear. Lee (1928) and Edgar \& Asdell (1960) have suggested that the junction may be an integral part of the spermatozoan transport mechanism. Other attributes that influence spermatozoan transport have been ascribed to the utero-tubal junction. Leonard \& Perlman (1949) injected live and dead rat and foreign spermatozoa, as well as India ink particles, into the uteri of oestrous and dioestrous rats and observed that motile rat spermatozoa freely traversed the utero-tubal junction, while immotile spermatozoa and inert particles did not. Foreign spermatozoa passed through the junction only very rarely. Because of their results, they suggested that motility of rat spermatozoa is essential for migration through the utero-tubal junction. Since foreign spermatozoa rarely traversed the utero-tubal junction, this structure was thought to display a species selectivity that might be related to spermatozoan morphology. In the cow, spermatozoan motility is not essential for passage through the utero-tubal junction (van Demark, 1953) while Phillips \& Andrews (1937) have shown that rat spermatozoa can be transported through the junction of the ewe.

The purposes of this investigation were to determine whether spermatozoan motility was necessary for transport through the utero-tubal junction of the oestrous rat and to determine whether the utero-tubal junction would prevent the passage of foreign spermatozoa.

\footnotetext{
* Contribution No. 54 of the University of Massachusetts, College of Agriculture Experiment Station, Amherst, Massachusetts, U.S.A.

$\dagger$ Present Address: Department Physiology and Biophysics, College of Medicine, University of Vermont, Burlington, Vermont, U.S.A.
} 
Normal, cycling albino rats were inseminated at the time of vaginal oestrus with immotile rat, rabbit, bull or human spermatozoa either alone or in various combinations. Ejaculates of semen were obtained from the rabbit, bull and man, while rat spermatozoa were removed from excised vasa deferentia. All samples of spermatozoa were diluted in calcium-free Ringer's solution at $25^{\circ} \mathrm{C}$, washed three times, and resuspended in Ringer's solution. Non-motility of diluted samples was confirmed microscopically and the cell concentration of each sample was determined by counting in a standard haemocytometer.

At mid-ventral laparotomy, $0.1 \mathrm{ml}$ of uterine fluid was withdrawn from each uterine horn prior to uterine deposition of $0.1 \mathrm{ml}$ of spermatozoan suspension with a syringe and 24 gauge hypodermic needle. In one group of animals, a silk ligature was placed just above the cervix (cervical ligature). Animals were killed with ether at varying intervals after insemination and as soon as possible a ligature was placed at the utero-tubal junction to prevent post-mortem entry of uterine material into the oviduct. In addition, a cervical ligature was placed in those animals bearing no such ligature at the time of insemination.

After death, the ovaries and oviducts were removed and placed in Ringer's solution at $37^{\circ} \mathrm{C}$. The oviducts were carefully dissected away from the ovaries, and their contents were expressed. Smears were prepared from this material with as little dilution as possible. Smears of the contents of the uterus flushed out with Ringer's solution were likewise prepared. All smears were air-dried and stained overnight in a dilute solution (1:50) of Delafield's haematoxylin. This procedure stained each type of spermatozoa so that it could be accurately identified. The ovaries and a segment of each uterine horn were fixed in Bouin's fixative, embedded in paraffin, sectioned and stained with haematoxylin-eosin for histological examination. Microscopic examination of the ovaries was used to confirm the stage in the oestrous cycle.

To avoid contamination by spermatozoa from previous trials, all glassware was cleaned with a detergent, soaked in a strong cleaning solution (potassium dichromate-sulphuric acid) for 3 to 4 days, rewashed, and coated with silicone before each use. Hypodermic needles used for insemination were washed, soaked in acetone for 5 to $6 \mathrm{hr}$, rewashed, and silicone coated. These procedures were effective in preventing contamination detected in some preliminary trials.

PASSAGE OF IMMOTILE RAT AND FOREIGN SPERMATOZOA THROUGH THE UTEROTUBAL JUNCTION OF RATS BEARING A GERVICAL LIGATURE

One-tenth $\mathrm{ml}$ of immotile rat, bull, rabbit or human spermatozoa suspension containing 92,000 to 6 million sperm cells was injected into each uterine horn of oestrous rats following cervical ligation. At intervals after insemination ranging from $1 \mathrm{hr} 30 \mathrm{~min}$ to $10 \mathrm{hr} 15 \mathrm{~min}$ the animals were killed and smears of uterine and oviduct contents were prepared. Spermatozoa were found in at least one oviduct of all animals inseminated (Table 1). While only a few intact spermatozoa were found in any one oviduct (up to five spermatozoa), this low number appeared to be independent of spermatozoa type, number inseminated or interval between insemination and death. These results clearly indicate that 
immotile rat, rabbit, bull and human spermatozoa can pass through the uterotubal junction of oestrous rats bearing a cervical ligature. There appeared to be no selection against the passage of foreign spermatozoa.

TABLE 1

PASSAGE OF IMMOTILE SPERMATOZOA FROM DIFFERENT SPECIES THROUGH THE UTERO-TUBAL, JUNGTION OF THE OESTROUS RAT, Following Gervical Ligation. Group 1

\begin{tabular}{c|l|r|rr|r|r}
\hline $\begin{array}{c}\text { Experiment } \\
\text { No. }\end{array}$ & $\begin{array}{c}\text { Species } \\
\text { of sperm }\end{array}$ & $\begin{array}{c}\text { No. sperms* } \\
\left(\times 10^{3}\right)\end{array}$ & $\begin{array}{c}\text { Examination time } \\
(\text { postinsemination }) \\
(\text { hr })\end{array}$ & $\begin{array}{c}\text { No. } \\
\text { (min) })\end{array}$ & $\begin{array}{c}\text { No. oviducts } \\
\text { oviducts } \\
\text { examined }\end{array}$ & $\begin{array}{c}\text { which } \\
\text { sperms detected }\end{array}$ \\
\hline 1 & Rat & 92 & 4 & 0 & 2 & 2 \\
2 & Rat & 1292 & 1 & 30 & 2 & 1 \\
3 & Rat & 320 & 6 & 0 & 2 & 1 \\
4 & Rat & 980 & 2 & 0 & 2 & 1 \\
5 & Bull & 348 & 10 & 15 & 2 & 2 \\
6 & Bull & 6800 & 3 & 15 & 2 & 2 \\
7 & Bull & 3400 & 4 & 30 & 2 & 2 \\
8 & Bull & 3350 & 4 & 45 & 2 & 2 \\
9 & Human & 3560 & 4 & 0 & 2 & 2 \\
10 & Human & 3560 & 4 & 0 & 2 & 2 \\
11 & Human & 3560 & 4 & 15 & 2 & 2 \\
12 & Human & 1280 & 4 & 15 & 2 & 2 \\
13 & Rabbit & 6000 & 3 & 0 & 2 & 2 \\
14 & Rabbit & 6000 & 3 & 15 & 2 & 2 \\
15 & Rabbit & 6000 & 3 & 15 & 2 & 2 \\
16 & Rabbit & 6000 & 3 & 30 & 2 & 2 \\
\hline
\end{tabular}

* Number of spermatozoa injected into each uterine horn.

TABLE 2

SIMULTANEOUS INSEMINATION OF IMMOTILE RAT AND BULL SPERMATOZOA into THE OESTROUS RAT FOLLOWING GERVICAL LIGATION. Group 2

\begin{tabular}{|c|c|c|c|c|c|c|c|c|}
\hline \multirow{2}{*}{$\begin{array}{l}\text { Experiment } \\
\text { No. }\end{array}$} & \multicolumn{4}{|c|}{ Sperm cells inseminated ${ }^{*}$} & \multicolumn{2}{|c|}{$\begin{array}{l}\text { Examination time } \\
\text { (postinsemination) }\end{array}$} & \multicolumn{2}{|c|}{$\begin{array}{l}\text { Sperms detected } \\
\text { in the oviduct }\end{array}$} \\
\hline & $\begin{array}{l}\text { Right } \\
\text { uterus }\end{array}$ & $\begin{array}{l}\text { No. sperms } \\
\left(\times 10^{3}\right)\end{array}$ & $\begin{array}{c}\text { Left } \\
\text { uterus }\end{array}$ & $\begin{array}{l}\text { No. sperms } \\
\left(\times 10^{3}\right)\end{array}$ & $(h r)$ & $(\min )$ & Right & Left \\
\hline 1 & Bull & 2090 & Rat & 3200 & 1 & 30 & + & + \\
\hline 2 & Bull & 2000 & Rat & 3200 & 2 & 30 & + & 0 \\
\hline 3 & Bull & 540 & Rat & 560 & 4 & 20 & + & t \\
\hline 4 & $\begin{array}{l}\text { Bull } \\
\text { Rat }\end{array}$ & $\begin{array}{l}448 \\
548\end{array}$ & $\begin{array}{l}\text { Bull } \\
\text { Rat }\end{array}$ & $\begin{array}{l}448 \\
548\end{array}$ & 12 & 0 & $+\dagger$ & $+\dagger$ \\
\hline 5 & $\begin{array}{l}\text { Bull } \\
\text { Rat }\end{array}$ & $\begin{array}{l}102 \\
128\end{array}$ & $\begin{array}{l}\text { Bull } \\
\text { Rat }\end{array}$ & $\begin{array}{l}102 \\
128\end{array}$ & 1 & 30 & $+\dagger$ & $+\dagger$ \\
\hline
\end{tabular}

* Number of spermatozoa injected into each uterine horn.

$\dagger$ Denotes both types of sperm cells present.

Since all animals in Group 1 were inseminated with one type of spermatozoa, any species selectivity displayed by the utero-tubal junction would have to be determined from comparisons between animals. In a second group of rats, rat spermatozoa were introduced into one uterine horn while bull spermatozoa 
were used in the opposite horn. Even under these conditions there appeared to be no selection between rat and bull spermatozoa (Table 2). The number of cells recovered from the oviducts was comparable to that of Group 1.

MIGRATION OF IMMOTILE RAT AND FOREIGN SPERMATOZOA THROUGH THE UTEROTUBAL JUNCTION OF RATS HAVING NO GERVICAL LIGATURE

Cervical ligation, while having the advantage of retaining spermatozoa within the uterus, has the disadvantage of creating abnormal conditions. In an attempt to simulate more closely the conditions normally found in the genital tract, and to remove the possible advantage of large numbers of spermatozoa held in the uterus by cervical ligation, spermatozoa were injected into uteri of oestrous rats with no cervical ligature. The incidence of oviducts containing spermatozoa from this group was lower than that found in the other groups (Table 3).

TABLE 3

MIGRATION OF RAT AND FOREIGN SPERMATOZOA FOLLOWING UTERINE INSEMINATION WITH NO CERVICAL LIGATURE. GROUP 3

\begin{tabular}{|c|c|c|c|c|c|c|c|c|}
\hline \multirow{3}{*}{$\begin{array}{c}\text { Experiment } \\
\text { No. }\end{array}$} & \multicolumn{4}{|c|}{ Sperm cells inseminated* } & \multirow{2}{*}{\multicolumn{2}{|c|}{$\begin{array}{l}\text { Examination time } \\
\text { (postinsemination) }\end{array}$}} & \multirow{2}{*}{\multicolumn{2}{|c|}{$\begin{array}{l}\text { Sperms detected } \\
\text { in the oviduct }\end{array}$}} \\
\hline & \multirow{2}{*}{$\begin{array}{l}\text { Right } \\
\text { uterus }\end{array}$} & \multirow{2}{*}{$\begin{array}{c}\text { No. sperms } \\
\left(\times 10^{3}\right)\end{array}$} & \multirow{2}{*}{$\begin{array}{c}\text { Left } \\
\text { uterus }\end{array}$} & \multirow{2}{*}{$\begin{array}{c}\text { No. sperms } \\
\left(\times 10^{3}\right)\end{array}$} & & & & \\
\hline & & & & & $(h r)$ & $(\min )$ & Right & Left \\
\hline 1 & Bull & 2500 & Rat & 2216 & 4 & 30 & + & + \\
\hline 2 & Bull & 272 & Rat & 128 & 4 & 15 & + & + \\
\hline 3 & Rabbit & 1800 & Rat & 1680 & 4 & 55 & + & + \\
\hline 4 & Rabbit & 1800 & Rat & 1680 & 4 & 5 & 0 & 0 \\
\hline 5 & Human & 1168 & Rat & 1476 & 2 & 50 & + & + \\
\hline 6 & Human & 1168 & Rat & 1476 & 3 & 0 & 0 & + \\
\hline 7 & Rat & 800 & Rat & 800 & 4 & 10 & 0 & 0 \\
\hline 8 & Rabbit & 840 & Rabbit & 840 & 4 & 20 & + & + \\
\hline 9 & Rabbit & 840 & Rabbit & 840 & 2 & 5 & 0 & 0 \\
\hline 10 & Rat & 800 & Rat & 800 & 2 & 15 & 0 & 0 \\
\hline 11 & Rabbit & 840 & Rabbit & 840 & 3 & 0 & 0 & 0 \\
\hline
\end{tabular}

* Number of spermatozoa injected into each uterine horn.

While large numbers of spermatozoa were discharged from the uteri of these animals, both rat and foreign spermatozoa were capable of passage through the utero-tubal junction. There was, again, no evidence of selection against foreign spermatozoa.

\section{DISCUSSION}

Although our knowledge of spermatozoan transport mechanisms remains incomplete, the fact is generally accepted that the reproductive tract, by means of its own activity, is primarily responsible for gamete transport. Our data support this general idea since it was found that immotile rat, rabbit, bull and human spermatozoa can be transported from the uterus to the oviduct. Not only can immotile spermatozoa be transported up the uterus and oviducts but they can also pass through the utero-tubal junction. While motility is not essential, this does not infer that immotile spermatozoa penetrate the uterotubal junction as freely as motile ones. 
The present observations do not indicate that the utero-tubal junction of the oestrous rat displays selectivity against passage of foreign spermatozoa. These findings are in agreement with transport of foreign spermatozoa through the utero-tubal junction of other animals (guinea-pig, Yochem, 1929; ewe, Phillips \& Andrews, 1937). The discrepancy between our results and those of Leonard \& Perlman (1949) is difficult to explain. It is possible that the expulsion of spermatozoa into the vagina following uterine insemination may be partly responsible, since these authors utilized a number of animals with no cervical ligation. However, in our experiments, even without cervical ligation, the passage of immotile rat and foreign spermatozoa through the utero-tubal junction was observed.

The number of spermatozoa recovered from oviducts was lower than that obtained by Blandau \& Odor (1949) and Braden \& Austin (1954). Both of these reports involved recovery of spermatozoa after normal mating. The absence of a copulatory stimulus and the use of immotile spermatozoa in our experiments may partly account for the low number of spermatozoa observed.

During microscopic examination of smears prepared from tubal contents, only intact spermatozoa were used in counting the number present. Because only intact spermatozoa were counted, and not all the tubal contents were used to make smears, this figure could in no way be considered to be the total number of spermatozoa present in the tube. For the purpose of this experiment the presence of only a few intact cells in the tube was considered sufficient evidence of transport.

Only four animals in Groups 1 and 2 (Nos. 1, 2 and 5 of Group 1 and No. 4 of Group 2) had fewer than ten spermatozoa in the smear of uterine contents. Microscopic examination of the smears and uterine mucosa of these animals did not reveal excessive leucocytic phagocytosis nor was there evidence that spermatozoa had entered the uterine mucosa. Whether or not spermatozoa have the ability to penetrate the uterine mucosa remains questionable and may vary among species (Posalaky \& Toro, 1957; Austin, 1960). Why spermatozoa disappeared from the uterus of some animals and not others is unknown. It is not likely that the time interval between insemination and death was responsible since it varied over a wide range $\left(1 \frac{1}{2}\right.$ to $\left.12 \mathrm{hr}\right)$. It is possible that leakage from the needle puncture may have occurred in spite of precautions.

\section{ACKNOWLEDGMENTS}

The authors express their appreciation to Miss Shirley DiBenedetto for her technical assistance. This investigation was supported by the North-eastern Cooperative Regional Project NE-41 'Endocrine Factors Affecting Reproduction and Lactation' and by funds from the Animal Husbandry Research Division, A.R.S., Beltsville, Maryland, U.S.A.

\section{REFERENGES}

Austin, C. R. (1960) Fate of spermatozoa in the female genital tract. F. Reprod. Fertil. 1, 151.

BLANDAU, R. J. \& ODOR, D. L. (1949) Total number of sperm reaching various segments of reproductive tract in female albino rat after insemination. Anat. Rec. 103, 93.

Braden, A. W. H. \& Austin, G. R. (1954) The number of sperms about the eggs in mammals and its significance for normal fertilization. Aust. F. biol. Sci. 7, 543. 
Edgar, D. G. \& Asdell, S. A. (1960) The valve-like action of the utero-tubal junction of the ewe. 7. Endocrin. 21, 315.

LEe, F. C. (1928) The tubo-uterine junction in various animals. Bull. Fohns Hopkins Hosp. 42, 335.

Leonard, S. L. \& Perlman, P. L. (1949) Conditions affecting the passage of sperm through the uterotubal junction of the rat. Anat. Rec. 104, 89.

Phillips, R. W. \& Andrews, F. M. (1937) The speed of travel of ram spermatozoa. Anat. Rec. 68, 127.

Posalaky, Z. \& ToRo, I. (1957) Experimental investigations into the destiny of spermatozoa not participating in fertilization. Acta biol. Acad. Sci., Hungary, $8,1$.

Van Demark, N. L. (1953) Physiological processes involved in sperm transport in cow. Mammalian Germ Cells, Ed. G. E. W. Wolsteholme. Little-Brown, Boston.

Yochem, D. E. (1929) Spermatozoan life in the female reproductive tract of the guinea pig and rat. Biol. Bull. 56, 274. 